\title{
[Rec.:] Paweł Perzyna, Błażej Stolarski. 1880-1939. Biografia społecznika, działacza gospodarczego i polityka, Łódź-Warszawa 2017, ss. 479 + fot.
}

Autor prezentowanej pracy, dr Paweł Perzyna, z pożytkiem dla miłośników historii, nie tylko Łodzi i województwa łódzkiego, od wielu już lat kieruje, jako naczelnik, Oddziałem Archiwum Instytutu Pamięci Narodowej w Łodzi. Jest absolwentem historii, którą ukończył w 1991 r. Mimo licznych obowiązków służbowych, nie tracąc kontaktu z macierzystym Instytutem Historii UŁ, przygotował - pod kierunkiem naukowym cenionego badacza międzywojnia, prof. dr. hab. Kazimierza Badziaka - biografię poświęconą czołowej postaci polskiego ruchu ludowego, Błażejowi Stolarskiemu. Stała się ona w 2014 r. podstawą, po wzorowo przeprowadzonej obronie, nadania Autorowi stopnia doktora nauk humanistycznych w dziedzinie historii. Jednocześnie, po kilku latach badań uzupełniających i zabiegów redakcyjnych, przybrała postać monumentalnego wydawnictwa książkowego, które niniejszym prezentujemy naszym czytelnikom.

Podejmując oryginalny trud badawczy, związany z potrzebami naszej najnowszej historiografii, P. Perzyna znalazł się w sytuacji mało komfortowej dla badacza. Okazało się bowiem, że gdy miał już opracowaną koncepcję pracy i zebrane materiały źródłowe, została opublikowana, przez prof. Antoniego Mieczkowskiego z Uniwersytetu Marii Curie-Skłodowskiej, książka „Błażej Stolarski 1880-1939. Życie. Działalność. Poglądy” (Lublin 1998, ss. 175). Wybrnął jednak z tego swoistego impasu prawno-autorskiego, oceniając dzieło czołowego badacza polskiego ruchu ludowego z Lublina jako opracowanie głównie o charakterze politologicznym, prezentujące poglądy Stolarskiego na rolę chłopów w dziejach najnowszych Polski i wizję ustrojową przyszłej ludowej Polski. Dlatego mógł z powodzeniem kontynuować i rozwijać prace badawcze w szerszym od dotychczasowych publikacji zakresie oraz podjąć szczegółowo zagadnienia związane z życiem rodzinnym i działalnością społeczno-gospodarczą i polityczną niezwykłego chłopa, polityka i społecznika.

Bohater książki P. Perzyny to człowiek skromny, może nawet zwyczajny, kreujący swoim aktywnym życiem biografię interesującą i pouczającą dla potomnych. Autor, podążając tropem badaczy, którzy dotychczas zajmowali się B. Stolarskim, nie zaliczył go do „grona pierwszoplanowych aktorów sceny politycznej i społecznej II Rzeczypospolitej”. Wydaje się, że przy tym przejął się, może nadmiernie, opinią wymienionego już prof. A. Mieczkowskiego, iż działacz ten „nie był politykiem dużego formatu”. Łatwo bowiem uzasadnić to, że Stolarski nie równał się pozycją męża stanu i charyzmą z Wincentym Witosem (którego zresztą był oponentem) czy Maciejem Ratajem. Niemniej jednak - ze swoimi osiągnięciami, wszechstronnym dorobkiem społeczno-gospodarczym i politycznym - należał do grona czołowych animatorów ruchu ludowego czasów międzywojnia. Z perspektywy doświadczeń dziejowych Polaków jego postawa może budzić zainteresowanie, a nawet podziw najnowszych pokoleń, do czego zapewne przyczynia się P. Perzyna. 
Baza źródłowa, zgromadzona do napisania prezentowanej książki, zasługuje na bardzo wysoką ocenę. Spełnia zasadniczy postulat, jaki stawia się przed pracą naukową, przede wszystkim w naukach humanistycznych i społecznych, polegający na wyczerpującym zgromadzeniu i obiektywnym wykorzystaniu wszelkich materiałów, które pozwoliłyby prawdziwie przedstawić badany przedmiot. Na tle zasobów źródłowych dotychczas uwzględnianych przez biografów Stolarskiego, praca P. Perzyny imponuje bogactwem materiałów, pozyskanych dzięki olbrzymiemu zaangażowaniu heurystycznemu, głównie zaś w siedmiu archiwach centralnych, terenowych i partyjnych oraz trzech bibliotekach. Tak więc autor czerpał szeroko ze zbiorów, które dotychczas nie były wykorzystywane przez naukowców piszących o Stolarskim.

Poza wykorzystanymi źródłami drukowanymi typu: akta normatywne, druki, sprawozdania, wydawnictwa źródłowe i urzędowe, dzienniki i pamiętniki, Autor odnalazł i po raz pierwszy poddał analizie nieznane do tej pory artykuły prasowe napisane przez B. Stolarskiego i opublikowane w takich periodykach, jak: „Łowiczanin” (1921), „Życie Łowickie” (1927), „Rolnictwo” (1929, 1935) i „Rozwój” (1913, 1919-1926).

Wszechstronne wykorzystanie dostępnych źródeł, pozbawiony emocji stosunek do istniejących już ocen działalności i życia B. Stolarskiego, a nade wszystko uczciwość badawcza, pozwoliły Autorowi zbudować dzieło o „gospodarzu ze Sługocic” wyważone w sądach i tym samym zajmujące trwałe miejsce w naszej historiografii, a przy tym niedające się wykorzystać w żaden sposób do prowadzenia modnej ostatnio, nie tylko w publicystyce, tzw. polityki historycznej.

Książka została opracowana w układzie chronologiczno-rzeczowym, który zapewnił jej przejrzystość i logiczne podporządkowanie celowi. Pozwoliło to autorowi ukazać życie Stolarskiego od urodzenia, w postępującym porządku czasowym, ze szczególnym zwróceniem uwagi na ewoluującą aktywność społeczno-gospodarczą i polityczną we własnym gospodarstwie, wsi, regionie i państwie.

Całość została poprzedzona wstępem, w którym Autor określił cel pracy i sformułował hipotezy dotyczące ocen bohatera swojej monografii. Tutaj też, prezentując solidny „oddech” metodologiczny, określił nowoczesne podejście analityczne, niezbędne do obiektywnego przedstawienia sylwetki i dokonań Stolarskiego. Pozwoliło to zrealizować trudne zadanie „zachowania obiektywnej oceny opisywanej postaci” (s. 9).

Rozdział 1 (Droga do awansu społecznego i wielkiej polityki) przedstawia najpierw „środowisko rodzinne i własne gospodarstwo wiejskie” oraz środowisko lokalne, które miało przemożny wpływ na kształtowanie się systemu wartości społecznych, pielęgnowanych i zrealizowanych przez B. Stolarskiego w dorosłym życiu. Przekonująco prostuje informacje biografów tego działacza, dotyczące pełnienia przez niego funkcji sołtysa Sługocic i wójta gminy Będków. Opisuje jego drogę do zdobycia prestiżu we własnym środowisku i później na szczeblu centralnym oraz podczas usamodzielniania się kółek rolniczych jako chłopskiej organizacji związkowej, zaznaczając przy tym, iż karierę polityczną rozpoczął w okresie I wojny światowej. Brał bowiem udział w pracach - powołanej 6 XII 
1916 r. przez niemieckie i austriackie władze okupacyjne - Tymczasowej Rady Stanu, jako namiestnik przedstawicielstwa polskiego. Już w Niepodległej został ministrem bez teki w rządzie lubelskim Ignacego Daszyńskiego i ministrem rolnictwa w gabinecie Jędrzeja Moraczewskiego. W tym miejscu warto się zastanowić, dlaczego Stolarski, zainspirowany początkowo do działań społecznikowskich przez endecję, znalazł się jako działacz, a z czasem i przywódca, w Polskim Stronnictwie Ludowym (zabór rosyjski) i PSL „Wyzwolenie”; partii, której program opracował twórca tzw. socjalizmu bezpaństwowego, czyli Edward Abramowski.

Rozdział 2 (Apogeum osiqgnięć i uznania w latach 1919-1922) prezentuje najlepszy okres życia politycznego B. Stolarskiego, który rozpoczął się w listopadzie 1918 r. Biorąc aktywny udział w budowie zrębów państwa odradzającego się w formie republiki liberalno-demokratycznej, obejmował przywództwo w PSL „Wyzwolenie” i w klubie parlamentarnym tej partii, a także zabiegał o przeprowadzenie reformy rolnej, upowszechnienie oświaty i usamodzielnienie się Związku Kółek Rolniczych jako organizacji chłopskiej. Przy tym nie zaniechał aktywności w lokalnym samorządzie terytorialnym. Zapewne aktywność tego działacza miała wpływ na wyniki wyborów parlamentarnych z 1922 r., najlepsze dla partii chłopskich w okresie II Rzeczypospolitej, gdy niemal połowa elektoratu chłopskiego oddała swoje głosy na partie, jeszcze rozproszonego do 1931 r., ruchu ludowego. Udanie ugruntował swoją pozycję parlamentarną na trzy kolejne kadencje, do roku 1930.

Rozdział 3 (W drugim szeregu ludowców. Od wyborów 1922 roku do wyborów brzeskich) przedstawia B. Stolarskiego podczas schodzenia na „boczny tor wielkiej polityki w Stronnictwie i Sejmie” oraz jednocześnie szczegółowo opisuje coraz większą aktywność jego działań w ruchu związkowym i spółdzielczym środowiska wiejskiego. I wreszcie eksponuje jako miłośnika i animatora swojej „,małej ojczyzny”, którą sytuuje na terenie wsi rodzinnej, gminy Będków i powiatu brzezińskiego. Wówczas patriota staje się także regionalistą. Potwierdza to autorstwem książki „Sługocice. Obraz życia i pracy jednej wioski” (Warszawa 1925) i tym samym włącza się aktywnie w obręb regionalizmu, ruchu społeczno-kulturalnego rodzącego się i rozwijającego od lat 20. XX w. To uogólnienie słusznie i w sposób uzasadniony zostało wyeksponowane w książce P. Perzyny.

Rozdział 4 (Powrót na pierwszy plan) przedstawia ostatni okres wielokierunkowej działalności „gospodarza ze Sługocic”. Ten czas aktywności Stolarskiego jest przedstawiony, podobnie jak poprzedni, bardzo szczegółowo.

Jego aktywność społeczno-polityczna i gospodarcza „obfitowała - jak zaznacza Autor - w zaskakujące zwroty akcji. Z jednej strony brał on udział w budowie Stronnictwa Ludowego, a z drugiej - uczestniczył w secesji grupy działaczy z tej partii i wstąpił do Obozu Zjednoczenia Narodowego. Z ramienia tego ugrupowania, po dwóch kadencjach spędzonych poza parlamentem, uzyskał mandat senatora i objął funkcję wicemarszałka Senatu. Kiedy obóz rządowy przeprowadzał unifikację organizacji rolniczych, Stolarski zakładał Związek Zawodowy Rolników o marginalnym znaczeniu społecznym i organizował strajki rolne. Po 1935 roku natomiast włączył się z zapałem do pracy w ramach Centralnego 
Towarzystwa Organizacji i Kółek Rolniczych, Związku Spółdzielni Rolniczych i Zarobkowo-Gospodarczych oraz powstającej Łódzkiej Izby Rolniczej. W tym samym mniej więcej czasie, po przejściowym rozbracie z brzezińskim samorządem, Stolarski ponownie został radnym sejmiku i członkiem wydziału powiatowego w Brzezinach".

Swoistego symbolu, w kontekście rozważań rozdziału zamykającego książkę, nabiera symboliczne zestawienie jednoczesnego odejścia B. Stolarskiego i Jego Ojczyzny. Został zamordowany wówczas, gdy ginęła II Rzeczpospolita. Gdy P. Perzyna skończył pisanie swego dzieła, jeszcze nie można było ustalić „w jakich okolicznościach, kiedy i gdzie Niemcy zamordowali Błażeja Stolarskiego" i gdzie znajduje się Jego grób. Ostatecznie jednak, po latach żmudnych poszukiwań, tę zagadkę dotyczącą ostatnich chwil życia „gospodarza ze Sługocic” udanie rozwiązał sam Autor [patrz w tym tomie: P. Perzyna, Epilog życia Błażeja Stolarskiego. Suplement do biografii].

Wartość poznawczą i poziom merytoryczny książki o B. Stolarskim znacznie wzmacnia jej Zakończenie, będące kompetentnie opracowaną syntezą. Autor określa w nim bohatera swego dzieła jako „wybitnego aktywistę społecznego i gospodarczego”, rolnika „zasłużonego do budowania zrębów nowoczesnego rolnictwa polskiego”, „zdolnego samorządowca” i „polityka dalszych szeregów partyjnych i parlamentarnych”. Jednakowoż konsekwentnie nie traktuje Go jako „pierwszoplanowego aktora sceny politycznej i społecznej II Rzeczypospolitej”. Zapewne jednak, wobec wyników własnego trudu badawczego i generalnie docenienia osiągnięć w każdej dziedzinie życia społecznego, gospodarczego i politycznego „gospodarza ze Sługocic”, zdaje sobie sprawę z relatywności owej oceny. Za przyczynę Jego „drugoplanowości” uznał brak wykształcenia, chociaż jednocześnie docenił rolę samokształcenia w budowaniu pozycji politycznej innych postaci, niejako pierwszoplanowych wśród elit chłopskiego ruchu społeczno-politycznego, chociażby Wincentego Witosa i Jakuba Bojki. Niemniej jednak zaliczył swojego bohatera do postaci kreujących znacząco politykę polską podczas procesu odradzania się państwa po czasach niewoli narodowej oraz w okresie II Rzeczypospolitej.

Wysoko oceniam poziom edytorski pracy, starannie wydanej przez Instytut Pamięci Narodowej - Komisję Ścigania Zbrodni przeciwko Narodowi Polskiemu, Oddział w Łodzi. Estetykę książki znacznie wzbogaca wartościowy materiał ikonograficzny. Fotografie, niektóre unikatowe z archiwów rodzinnych, dobrze ilustrują zasadnicze wydarzenia z bogatego życiorysu B. Stolarskiego.

Całość źródłowo uzupełniają, zamieszczone w trzech aneksach, interpelacje i wnioski tego działacza złożone w Sejmie Ustawodawczym oraz Sejmach RP I i II Kadencji, świadczące przekonująco o jego inteligencji, wiedzy rolniczej i wrażliwości społecznej.

Obszerna Bibliografia, zawierająca wykaz źródeł archiwalnych, drukowanych, w tym pamiętników i wspomnień oraz prasy, a ponadto mieszcząca w sobie zestaw około 350 opracowań, stanowi na pewno ważną wskazówkę, a nawet inspirację do podejmowania dalszych badań nad historią polskiej myśli społeczno-politycznej. 
Lekturę tej wielkiej objętościowo, wręcz monumentalnej pracy, znacznie ułatwi zamieszczony na końcu Indeks osób występujących na kartach książki, czyli m.in.: autorów, polityków, twórców kultury, rodziny i przyjaciół B. Stolarskiego. Zawiera on niebanalną liczbę około 800 nazwisk.

Dogłębnie przedstawiona przez Autora charakterystyka B. Stolarskiego, pozwala zaliczyć Go, jak wiele postaci z różnych tzw. nowoczesnych ruchów społeczno-politycznych ukształtowanych na przełomie XIX i XX w., do „pokolenia historycznego", którego istota i funkcje działania związane były z określonymi datami procesu historycznego [Maria Ossowska, Koncepcja pokolenia, „Studia Socjologiczne" 1963, nr 2, s. 49]. Jako reprezentant tej generacji rozpoczynał tworzenie zrębów II Rzeczypospolitej, urodzony jeszcze w niewoli narodowej, ukształtowany w określonym kręgu kulturowym, w atmosferze istnienia narodu bez własnego państwa. Był przy tym obciążony świadomością, że jego stan społeczny, czyli chłopi w okresie I Rzeczypospolitej - w czasach folwarczno-pańszczyźnianych, traktowani jak niewolnicy - w zasadzie nie posiadali, z formalno-politycznego punktu widzenia, swojego państwa, a mimo to go „żywili i bronili”. Niemniej jednak, dla niego jako chłopa, sprawa odzyskania Polski była wartością nadrzędną. Za nią w kolejności podążały zabiegi o zbudowanie sprawiedliwej społecznie ojczyzny w postaci ludowej Polski. To stanowiło istotę jego patriotyzmu, jako tzw. państwowca. Dlatego, jak wynika z rozważań autora, B. Stolarski dobro ojczyzny przedkładał nad interesy partyjne. Nie można więc mieć do niego zbytnich pretensji o to, że zmieniał swoją przynależność do partii, a nawet obozów politycznych.

W świetle dociekań Autora trudno się zgodzić z pozbawionym głębszej argumentacji stanowiskiem Antoniego Miecznikowskiego, że „Stolarski akceptował libertyńsko-masońską koncepcję eliminacji obecności Kościoła rzymskokatolickiego z życia społecznego" (dz. cyt., s. 144-145). Warto sobie uświadomić, w kontekście tej opinii, że libertynizm, jako filozofia społeczna, zasadniczo różni się od liberalizmu, nie tylko w sferze obyczajowej, lecz także społeczno-politycznej. Bohater recenzowanej książki z pewnością opowiadał się za rozdziałem Kościoła od państwa, co sytuowało go wśród zwolenników myśli liberalno-demokratycznej i zasad organizowania państwa w duchu jej wartości. Zresztą Polska w ramach II Rzeczypospolitej, aż do przewrotu majowego w 1926 r., była klasycznym przykładem takiej właśnie nowoczesnej formy państwa. Jednocześnie, jako człowiek lewicy i zwolennik reform strukturalnych, szczególnie reformy rolnej, zdawał się przechylać w swoich poglądach w stronę socjaldemokracji. Natomiast ze względu na uzasadnione poglądy dotyczące chłopów i wsi, jako społecznych fundamentów państwa oraz gospodarki w polskich warunkach okresu międzywojnia, można usytuować go wśród agrarystycznych odcieni myśli socjaldemokratycznej.

Najnowsza publikacja P. Perzyny wprowadziła nowe i wiarygodne ustalenia do biografii „gospodarza ze Sługocic”. Podkreśliły one ważną rolę tego skromnego działacza chłopskiego w animowaniu ruchu ludowego, a także nietuzinkową pozycję w historii odrodzenia i funkcjonowania II Rzeczypospolitej. 
Książka ta jest bogata faktograficznie, bardzo szczegółowa; obiektywnie, z zachowaniem dystansu pozbawionego emocji, porządkuje wielokierunkowe działania i wpływy B. Stolarskiego oraz opinie o nim. Powstała jako wynik samodzielnej, żmudnej i dojrzałej naukowo aktywności Autora, zapewniając jemu samemu i jego pracy, wysoką pozycję w historiografii polskiej myśli społeczno-politycznej.

Andrzej Lech

Adres mailowy autora: jendrol1@interia.pl 